Portland State University

PDXScholar

Sociology Faculty Publications and

Presentations

Sociology

$12-2016$

\title{
Who's the Fairest of Them All? The Fractured \\ Landscape of U.S. Fair Trade Certification
}

Daniel Jaffee

Portland State University, jaffee@pdx.edu

Philip H. Howard

Michigan State University

Follow this and additional works at: https://pdxscholar.library.pdx.edu/soc_fac

Part of the Agricultural and Resource Economics Commons, and the Rural Sociology Commons

Let us know how access to this document benefits you.

\section{Citation Details}

Published as: Jaffee, D., Howard, P.H. Who's the fairest of them all? The fractured landscape of U.S. fair trade certification. Agric Hum Values 33, 813-826 (2016).

This Post-Print is brought to you for free and open access. It has been accepted for inclusion in Sociology Faculty Publications and Presentations by an authorized administrator of PDXScholar. Please contact us if we can make this document more accessible: pdxscholar@pdx.edu. 


\title{
WHO'S THE FAIREST OF THEM ALL? \\ THE FRACTURED LANDSCAPE OF U.S. FAIR TRADE CERTIFICATION
}

Daniel Jaffee and Philip H. Howard

This is the Accepted Manuscript (Author's Post-print) of an article published in the journal Agriculture and Human Values. Available online: https://doi.org/10.1007/s10460-009-9231-8

Citation: Daniel Jaffee ${ }^{1}$ and Philip H. Howard. 2016. "Who's the Fairest of them All? The Fractured Landscape of U.S. Fair Trade Certification." Agriculture and Human Values 33: 813826.

\begin{abstract}
In recent years, consumers in the United States have been confronted by no fewer than four competing fair-trade labels, each grounded in a separate certification system and widely differing standards. This fracturing is partly a response to the recent split by the U.S. certifier Fair Trade USA from the international fair trade system, but also illustrates longstanding divisions within the fair trade movement. This article explores the dynamics of competition among nonstate standards through content analyses of fair trade standards documents from the four U.S. fair-trade certifications for agrifood products (Fair Trade USA, Fairtrade America, Fair for Life, and the Small Producer Symbol). It analyzes the differences among them, asking what kinds of social and labor relations are facilitated by each, and identifies how closely they correspond with key fair trade principles. We make two primary arguments. First, we argue that the case of fair trade challenges the dominant conceptual model used to analyze competition among multiple private standards in a single arena, in which newer challengers lower the rigor of standards. Second, we contend that the current fractured U.S. certification landscape illuminates divisions among different interest groups over which principles — and which labor and production forms - should be privileged under the banner of fair trade.
\end{abstract}

\author{
ABBREVIATIONS: \\ CLAC: Latin American and Caribbean Coordinator of Fair Trade Producers \\ FLO: Fairtrade Labeling Organizations International \\ FTI: Fairtrade International \\ FTUSA: Fair Trade USA \\ IFAT: International Federation of Alternative Traders \\ ILO: International Labor Organization \\ IMO: Institute for Marketecology \\ NGO: Nongovernmental Organization \\ SMO: Social Movement Organization \\ SPP: Small Producers' Symbol (Símbolo de Pequeños Productores) \\ TNC: Transnational Corporation \\ WFTO: World Fair Trade Organization
}

${ }^{1}$ Department of Sociology, Portland State University, Portland, OR, USA. Email: jaffee@pdx.edu 


\section{WHO'S THE FAIREST OF THEM ALL?}

\section{THE FRACTURED LANDSCAPE OF U.S. FAIR TRADE CERTIFICATION}

\section{Daniel Jaffee and Philip H. Howard}

A few short years ago, U.S. consumers seeking to purchase fairly-traded food products could look on supermarket shelves for a single product seal, backed by the sole national fair trade certification body. Today, however, shoppers are confronted by no fewer than four competing fair-trade labels, each backed by a separate third-party certification system and grounded in widely varying standards, raising the potential for confusion and setting off competition among the seals to attract licensee firms. This fracturing is in part a response to the controversial 2012 departure of the U.S. certifier Fair Trade USA from the international fair trade system governed by Fair Trade International, or FTI (Rice 2012), but it also illuminates longer-running divisions within the U.S. fair trade movement over its increasing relationship with large corporate agrifood firms and the resulting changes in fair trade standards (Reed 2009).

Transfair USA lost its monopoly on fair trade certification in the U.S. in 2006, with the appearance of the Fair for Life seal, created by the Swiss organic certifier Institute for Marketecology (IMO). This was followed by the debut of two new labels in 2012. The first, Fairtrade America, was developed by FTI in reaction to Fair Trade USA's departure, and is based on its international standards (Fairtrade America 2013; Fairtrade International 2013b). The second label is the Small Producer Symbol (SPP, for the acronym in Spanish), created by CLAC, the Latin American and Caribbean assembly of organized fair trade producers within FTI (Preza 2012; Pruijn 2014). 
These developments raise intriguing questions regarding the dynamics of contention between multiple standards regimes within alternative agrifood movements. A substantial body of literature has examined fair trade as an exemplar of both nonstate private regulatory regimes and alternative agrifood movements (e.g., Renard 2003; Mutersbaugh 2005b; Raynolds et al. 2007; Lyon and Moberg 2010; Raynolds 2012). Much of this writing focuses on contestation within this international movement over the content of fair trade standards, including changes to these standards that some scholars have characterized as dilution, weakening, or cooptation (Renard 2005; Fridell et al. 2008; Jaffee 2010). Some work has compared fair trade with other eco-labels such as organics and their corresponding certification systems, charting the parallels and divergences between them (Jaffee and Howard 2010). Yet there is a paucity of scholarship that examines competing fair trade certifications within the same national context (exceptions include Renard and Loconto 2013 and Smith 2013), and no literature to date that explicitly compares the standards undergirding each of the rival U.S. fair trade certification systems. This is an important question because ecolabels, including fair trade, encompass multiple attributes, yet the relative emphasis different certifications place on a given attribute may not be obvious. It can be difficult for consumers - or in some cases even retailers and producers - to identify which elements, including those based on the original ideals of agrifood movements, are prioritized by different ecolabels.

This article explores the dynamics of competition among nonstate standards through content analyses of fair trade standards documents, with a focus on three main questions: (1) How specifically do the four primary fair trade certifications in the U.S. differ, and what kinds of economic and labor relations are facilitated by each?; (2) How closely do the standards underlying these seals correspond to the foundational principles of fair trade?; and (3) What does 
the fracturing of the U.S. fair-trade certification system signify about the dynamics of competition among nonstate standards?

The following section of the paper reviews the literature on the dynamics of competition among ecolabels and standards, followed by an examination of major debates and tensions within the fair trade movement that have led to increased competition in this realm. We then describe the methods of content analysis we apply to key documents from each of the four U.S. fair-trade seals, to analyze the content of their standards vis-a-vis these debates. We compare the seals on a number of variables, situating them as both a manifestation of ongoing intramovement tensions and a response to Fair Trade USA's break from the international system. The following section presents the results of a content analysis of standards documents from each certifier, and identifies how closely they align with the World Fair Trade Organization's Ten Principles of Fair Trade — a key document codifying movement principles — to analyze their degree of correspondence with fair trade's foundational ideals. The subsequent discussion revisits the question in the article's title by assessing the significance of the divergences and parallels among certifications, and asks how fair trade scholars, producers, and consumers might navigate in this newly fractured landscape. A concluding section takes stock of the key arguments and offers some observations on the future trajectory of the U.S. fair trade movement.

We make two primary arguments. First, we argue that the case of fair trade challenges the dominant conceptual model used to analyze competition among multiple private standards in a single arena, in which newer challengers lower the rigor of standards. Second, we contend that the present fragmented U.S. certification landscape illuminates preexisting divisions among different interest groups over which principles_ and which labor and production forms — should be emphasized under the banner of "fair trade." The opacity of the differences in these principles 
to consumers, and the resource disparities between the various seals, suggest that those initiatives with the most stringent standards may face significant barriers to success. Yet the "standards wars" that now characterize the field of fair-trade certification in the U.S. also offer intriguing new pathways for smallholder organizations and their allies to create alternative structures that hold potential for fulfilling the more transformative visions of fair trade's founders.

\section{Competition Among Standards}

Busch (2011) describes standards as "recipes for reality" that delineate what is acceptable or unacceptable to segments of society. While standards typically go unnoticed by most people, to those most affected by them, they are important sites of contestation. Consumer interest in ecolabels emerging from civil society--including organic, sustainable seafood, and sustainable forestry certifications--have led to the proliferation of such standards and rapid sales growth for the more successful initiatives (Raynolds et al. 2007; Howard and Allen 2010). In response to this growth, counter-efforts by dominant firms or interest groups have emerged. These responses tend to follow three broad strategies: weakening existing standards, undermining their legitimacy, or establishing competing standards and governance bodies (Hatanaka et al. 2012). While social movement organizations (SMOs) typically favor stringent, binding standards, corporations prefer less stringent, contractually-based standards with lower levels of enforcement (Bartley 2007; Mutersbaugh 2005a). The latter typically pose fewer barriers to conventional agricultural practices than the former (Jaffee and Howard 2010). In many settings third-party standards and certification developed by social movements or civil society have subsequently been challenged or replaced by weaker, first- or second-party certifications emerging from the very industry sectors that the original standards sought to regulate (Jaffee 2012). 
Weaker certifications may still have significant positive impacts, if the implementing organizations are large and the volumes of production they apply to are high (Schaltegger and Wagner 2011; Howard and Jaffee 2013) Support for weaker or diluted standards by dominant political and economic actors, however, has the potential to diminish alternatives based on stronger standards. Organic certification in the U.S., for example, is regulated by the USDA, and competing standards are not permitted to use the word "organic." From the perspective of social movement-oriented participants, therefore, the amelioration of some harms resulting from a lower but more widely applied bar may not be an acceptable tradeoff.

However, such standards competition need not necessarily lead to the demise of stronger, SMO-based regimes. For example, in the arena of sustainable forestry, Bartley (2007) traced the advent of Forest Stewardship Council certification, which was soon confronted by multiple competing labeling schemes in the U.S., Canada, and Europe, some developed by industry. He argued that ultimately "the ensuing mix of competition and adaptation helped turn forest certification into a dynamic, contentious, and rapidly growing field" (2007, p. 234). Smith and Fischlein examined several sustainability certification arenas characterized by what they term rival private governance networks, concluding that such rival schemes emerge "when relevant stakeholder groups are excluded and their legitimacy is threatened due to non-participation in this new governance domain" (2010, p. 520). Such broad analyses notwithstanding, little is known about specific cases in which a standards regime based in civil society is later challenged by multiple competing initiatives that strengthen — rather than weaken — the rigor of standards. Fair trade in the U.S. is one such case. 


\section{Fair Trade Standards: Key Debates}

Since the creation of FLO as the international certifier in 1997, a set of key issues has generated substantial contention among groups of fair trade movement actors. Despite major institutional and policy changes in the intervening decades, the primary areas of controversy have remained remarkably consistent.

\section{Governance dimensions}

Debates over governance in fair trade have revolved around two issues: the role of socialmovement or civil society groups in the decision-making structures of national licensing bodies, and the representation by small-producer organizations in the governance of FLO/FTI. With regard to the first issue, the U.S. case has been anomalous nearly from its inception. While the other national licensing initiatives in Europe and elsewhere emerged from and remained linked to a range of social movement organizations, which are largely are still represented in their governance structures, nearly from its inception Transfair USA (now FTUSA) has lacked meaningful participation by civil society in its governance, and developed a hierarchical administrative model in which the CEO exercises considerable power (Jaffee 2012; Raynolds 2012). In terms of the second issue, the role of organized producers in the governance of fair trade institutions has long been a point of contention. After more than a decade of pressure by Southern producer groups, who at FLO's inception had no voting representation, the certifier has gradually accepted a greater role for small producers on its decision-making bodies. As of 2014,

they hold half of the seats on FTI's General Assembly, and four of 11 seats on the more powerful board of directors (Bennett 2015)1. 


\section{Terms and effects of corporate participation}

The issue of increased corporate participation in fair trade in the U.S. and the terms on which that access was granted has generated major tensions between two groups of retail firms, which Jaffee (2007) terms movement-oriented (small and medium-sized ethical firms typically selling exclusively fair-trade products, such as Equal Exchange) and profit-oriented (medium or large firms drawn by the profits from growing demand, such as Starbucks or Dole). The former group alleged that the profit-oriented participants have caused fair trade standards to become watered down. Antagonized by what they perceived as their unfavorable treatment by the U.S. certifier, virtually all of the small and medium movement-oriented companies had by 2011 left Transfair certification, the same year it changed its name to Fair Trade USA (Jaffee 2012).

The entire FLO system has embraced a strategy of "mainstreaming" fair trade by selling certified products through conventional brands and retail channels in order to reach mass consumer audiences. The licensing deals struck with large TNCs in the ensuing years in both the U.S. and Europe-including Starbucks, Dole, Nestlé, McDonald's, Cadbury, and other major firms - have driven both a rapid growth of fair trade volumes, from less than \$1 billion in 2001 to over $\$ 7$ billion today (Fairtrade International 2013a), and changes to standards that expanded certification into new crops, geographies, and production forms, particularly agribusiness plantations employing waged laborers (Besky 2008; Dickinson 2011; Raynolds 2014). A related issue is the minimum threshold required for entry into the system. In the first years of U.S. certification, firms needed to purchase a minimum of $5 \%$ of their total volume of a given commodity under fair trade terms in order to use the label, but this element was dropped by 2000 when Starbucks entered with coffee purchases below one percent of its volume, leading to charges of free-riding by small firms (Jaffee 2012). This is linked to the "fairwashing" 
phenomenon, in which large firms use purchases of small amounts of fair trade products as part of corporate social responsibility strategies to enhance brand image, and/or firms with problematic records in human rights, labor, or environmental practices use selective engagement with fair trade to sanitize "bad actor" images and defuse activist pressure (Reed 2009; Renard 2010; Doherty et al. 2013).

Some scholars have used the concept of weakening or dilution to describe such changes to standards, which both occur in response to, and further facilitate, increased corporate involvement in fair trade - in this case by allowing firms to enter with no minimum purchase levels and permitting certification of labor and agricultural practices that would not have conformed previously (Fridell et al. 2008; Gogoi 2008; Jaffee and Howard 2010; Doherty et al. 2013).

Fair trade minimum prices and prepayment

The levels of the fair-trade minimum prices and premiums, particularly for coffee, have been another contentious issue for small producer groups in the FLO system for some years. These prices are the only element of fair trade standards that is actually redistributive (Jaffee 2010). The coffee base price established in 1988 — \$1.26 per pound of green coffee-was not indexed to inflation or rising producer costs and thus began losing purchasing power immediately (Bacon 2010). According to Bacon (2010), the coffee price had lost 41 percent of its real value even after modest increases by FLO in 2007 and 2008. Extending that analysis to the present, and factoring in a more substantial 2011 rise in the base prices, ${ }^{2}$ we calculate that the real value of the coffee base price as of 2014 was only 96 cents per pound, and it would need to rise to $\$ 2.70$ to regain its original 1988 value to producers. ${ }^{3}$ The payment of pre-harvest financing to producers was another central plank of fair trade's initial design. Originally, buyers 
were required by FLO to provide up to 60 percent of payment prior to harvest to avoid the classic smallholder debt trap, but this requirement is often not honored by firms (Raynolds 2009, p. 1089).

\section{Labeling and ingredients}

One of the more complex issues involves product labeling and the use of certified ingredients in multi-ingredient products such as chocolate bars, as contrasted with singleingredient products like roasted coffee. As these composite products grew, FLO/FTI allowed firms to use a different version of the fair trade label on the package for such products if their total fair trade content is as low as 20 percent. However, a recent survey indicates that most consumers do not perceive any difference between the standard or "full" fair-trade seals and the largely identical variants of these seals that indicate only a single fair-trade-certified ingredient (Lake Research Partners 2013). Thus, the arena of product and ingredient labeling potentially allows for a substantial degree of fairwashing.

\section{Plantations and hired labor}

The extension of certification to agribusiness plantations of food and nonfood crops is currently the most divisive issue within the global fair trade movement. FLO originally extended certification to plantations in tea, then bananas, and more recently other fresh fruit, wine grapes, and flowers (Besky 2010; Dickinson 2011). As of 2012 there were 187,500 hired laborers on FTI-certified plantations, an increase of 46 percent since 2008. Despite this growth, the fair trade market remains dominated by the products of small-producer organizations (Fairtrade International 2013a). The still-limited scope of plantation fair trade is due to the fact that several major crops - coffee, cocoa, sugar, honey, cotton, and rice, together representing 76 percent of total fair trade revenues - have remained closed to plantation production under FTI standards 
(Fairtrade International 2013b). There is strong opposition from small producer organizations to expanding plantation certification to these closed crops because most are still unable to sell the majority of their harvests at fair trade prices, due to insufficient demand (Renard and Loconto 2013; Renard 2015) ${ }^{4}$. Across all products, only 31 percent of these organizations' harvests were sold at fair trade terms in 2011 (Fairtrade International 2012).

In 2011, FTUSA broke from the FTI system to create its own certification, which for the first time permits unlimited certification of plantation-grown crops (Sherman 2012). FTUSA's rationale for this move was that hired laborers in plantation agriculture, whom CEO Paul Rice termed "the poorest of the poor," were being denied the benefits of fair trade, and that certification was an ideal tool to rectify labor rights abuses in global agribusiness (Neuman 2011; Rice 2012). Fair trade movement critics, however, charged that large firms would shift their existing fair trade supply chains from cooperatives to plantations and also expand the latter, further harming small producers (Neuman 2011; Zinn 2012).

The FTI (and now FTUSA) hired labor standards require firms using the seal to meet core ILO conventions, which prohibit discrimination and child or forced labor and require the payment of national minimum wages, although the latter is a standard widely viewed as inadequate in most of the global South. ${ }^{5}$ Employers must ensure workers' right to freedom of association, but not the presence of independent labor unions. Plantation owners are not required to pass on the income from higher fair trade sales prices to their workers, but the fair trade premiums are placed into a fund allocated by a "joint body" or "premium fund committee" consisting of both workers and management, whose composition and representativeness vary both within and among certifications (Besky 2008; Makita 2012). FTI in 2014 revised its hired 
labor standards with input from international unions, increasing protections for union organizing and adding sanctions against labor rights violations (Stevis 2015).

We now turn to discussing one of the primary results of this major institutional split: the proliferation of competing fair trade certifications in the U.S. market.

\section{Competing U.S. Fair Trade Labels}

This section briefly describes each of the four certifications compared in this analysis, addressing key areas of divergence as well as similarity, and describes the changes unleashed by these new "label wars."

\section{Fair Trade USA}

As the sole U.S. fair trade licensing body for 15 years, Transfair USA/FTUSA administered the international FLO/FTI standards and but also departed from international norms, as discussed above. Transfair USA was particularly active in facilitating the entry of large multinational firms, beginning with Starbucks in 2000, setting precedents for the entire fair trade system (Raynolds 2009) and causing a backlash (and later an exodus) by movementoriented firms. Since FTUSA's split from FTI, it has retained most of the large corporate firms, including Starbucks, Green Mountain Coffee, Dole, and McDonalds (Fair Trade USA 2015). These are players who benefit from the new freedom to certify supply chains based on hired labor in crops that remain closed to plantations under the FTI/Fairtrade America standards. IMO Fair for Life

Fair for Life, created by IMO and the Swiss Bio Foundation, departs from the FTI and FTUSA systems in several ways. It is open to a broad range of production types, including organized and unorganized producers, contract farmers, and plantations in any crop, as well as artisans, mining operations, and even tourism operations (Bio Foundation 2013). It applies to 
products from both the South and the North (Smith 2013, p. 15). Firms are audited based on a point system with several criteria, and need not receive $100 \%$ on all aspects to receive certification (IMO Fair for Life n.d.). The most significant difference is that Fair for Life requires auditing and inspection of the entire product chain in both South and North, including the business operations and labor practices of producers, buyers, and brandholders (Smith 2013). This addresses charges by labor activists that firms including Walmart use fair trade certification to fairwash violations of labor rights in both their production and retail settings. Several major brands have either adopted or switched to Fair for Life certification, including Dr. Bronner's, Guayaki Yerba Mate, and some Equal Exchange Products (Equal Exchange 2010). The seal has not been without controversy: a labor rights NGO charged that Fair for Life maintained Theo Chocolate's certification despite Theo's interference with a union organizing drive among its workers (International Labor Rights Forum 2013).

\section{Fairtrade America}

After Fair Trade USA broke from the FTI system to launch its own certification, FTI in 2012 debuted a new U.S. label called Fairtrade America, based on its international standards, with the blue-and-green fair trade logo now used in all consumer nations except the U.S. (Fairtrade America 2013; Fairtrade International 2013b). One major difference between FTUSA and Fairtrade America is in the realm of hired labor: the latter continues to exclude several major crops from plantation certification, and enforces FTI's more rigorous labor rights protections (Fair Trade USA 2012; Fairtrade International 2014a). Among the major brands that have switched from FTUSA to Fairtrade America are Ben \& Jerry's, Divine Chocolate, Green \& Black's, and Wholesome Sweeteners. The new certifier has not yet developed a substantial consumer education or marketing campaign. 


\section{Small Producer Symbol}

A fourth and final fair trade seal appeared in the U.S. in 2012, although it had been nearly a decade in the making. The Small Producer Symbol (SPP) was created by CLAC (representing 300 organizations in 21 Latin American nations), and is owned and administered by its Mexico City-based NGO, FUNDEPPO (Preza 2012; Pruijn 2014). As the name implies, SPP certification is available only to organized small producers ${ }^{6}$ and does not apply to hired labor. As of April 2014, sixty producer groups in Latin America had been certified, and SPP plans to expand to Africa and Asia (Fundeppo 2014a). The initiative has formulated both general and product-specific standards and set its own minimum prices (Fundeppo 2013a; Fundeppo 2013b; Fundeppo 2014b). The SPP system also incorporates several elements designed to avoid "fairwashing" and token participation by licensees: its Code of Conduct excludes firms whose practices violate the initiative's core principles (whether or not they meet the standards), and firms must purchase a minimum of 5 percent of their total volume under SPP certification by the second year of certification, rising by 5 percent annually to a minimum of 25 percent (Fundeppo 2010; Renard and Loconto 2013; Fundeppo 2013a).

\section{Methods: Content Analysis of Standards Documents}

The earlier stage of fair trade standards contestation in the U.S. (between 2000-2011) had involved mission-driven firms, activists, and NGOs opposing the weakening of standards by Transfair/FTUSA and by FLO/FTI. However, with virtually all of the mission-driven firms having left Transfair USA even before its 2011 split with FTI, the contention over standards has now shifted to a new phase, consisting of the appearance of multiple competing certifications within the same national market, making a detailed comparison of these standards important. In this comparison, we have included only the certifications that: (a) use fair trade as a primary, 
explicit element in their claims; (b) are currently available in the U.S. market on internationally traded agrifood products; and (c) use third-party certification. The analysis thus excludes other eco-labels for which social conditions of production are a secondary element (e.g., Rainforest Alliance or Utz), are unavailable in the U.S. (e.g., Eco-Cert), or do not employ third-party certification for food products sold in the U.S. (e.g.,WFTO seal). Based on these criteria, our analysis includes four certification systems: (1) Fair Trade USA, (2) IMO Fair for Life, (3) Fairtrade America, and (4) the Small Producer Symbol.

To compare and contrast these U.S. fair trade certifications, we conducted content analyses of several key standards documents from each of the four initiatives. The broader analysis also draws from other relevant certifier documents and NGO reports comparing fair trade seals. One emphasis of coding was to identify differences among the seals related to the key debates described above (governance dimensions; terms of corporate participation; prices and prepayment policies; labeling and ingredient requirements; and plantation and hired labor policies). Another emphasis of coding was to analyze the standards' degree of correspondence with the World Fair Trade Organizations's 10 Principles of Fair Trade (WFTO 2013). WFTO (formerly IFAT) is a pioneering international fair trade membership organization founded in 1989, with nearly 500 member organizations in over 70 nations in South and North and active involvement by organized producers of both agrifood and craft products. Its Principles, developed in the 1990s and last revised in 2013, are a key document that codifies fair trade movement principles. For this analysis we selected the three central standards documents for each of the four labels. These typically describe the organization's overall requirements for certification and list detailed requirements that apply to specific supply chain actors: small producers, hired labor settings, and traders (i.e. distributors or retailers). The twelve documents 
analyzed are listed in the sources for Figure 1. We used Dedoose qualitative analysis software to highlight document excerpts and code them with the ten principles to quantify the relative percentages of passages in each standard that correspond to each of the ten codes. Each author blind coded two documents, then we discussed all instances where we differed until full agreement was achieved. Based on this schema, one author coded the remaining documents, which were then checked by the other to ensure consistency.

\section{Results: Comparing U.S. Fair Trade Certifications}

Drawing on the comparison of these standards documents, we now turn to focusing in greater depth on four key sets of issues, linked to the debates discussed above, which highlight the divergences and parallels between these competing systems. ${ }^{7}$

\section{Institutional dimensions and governance}

Table 1 shows the four certifiers' institutional affiliations, some of their largest licensee firms, and the role of small producers in their governance. Fair for Life and Fairtrade America conduct their own certification and verification, while SPP uses various certification bodies ${ }^{8}$ and FTUSA employs SCS Global Services to administer its standards. As discussed above, small producers hold 36 percent of the seats on the FTI board and half the seats on its General Assembly. The Small Producer Symbol is fully owned by its organizational members of small producers, although two of six seats on its standards committee are held by fair trade buyer representatives (Renard and Loconto 2013). In contrast, neither FTUSA nor Fair for Life have any representation by organized small fair trade producers in their governance structures. 
TABLE 1: U.S. Fair Trade Certifications: Governance Dimensions; Pricing, Payment, and Auditing Policies

\begin{tabular}{|c|c|c|c|c|}
\hline & $\begin{array}{l}\text { Fair Trade USA } \\
\text { (FTUSA) }\end{array}$ & $\begin{array}{l}\text { Fairtrade America } \\
\text { (FTI) }\end{array}$ & Fair for Life & $\begin{array}{l}\text { Small Producers' } \\
\text { Symbol (SPP) }\end{array}$ \\
\hline $\begin{array}{l}\text { Year first certified } \\
\text { products sold in } \\
\text { U.S. }\end{array}$ & 1998 & 2012 & 2006 & 2012 \\
\hline $\begin{array}{l}\text { Parent } \\
\text { organization and } \\
\text { location }\end{array}$ & $\begin{array}{l}\text { Fair Trade USA } \\
\text { (Oakland, CA) }\end{array}$ & $\begin{array}{l}\text { Fairtrade International } \\
\text { (FTI, formerly FLO) } \\
\text { (Germany) }\end{array}$ & $\begin{array}{l}\text { IMO Group AG } \\
\text { (Switzerland) }\end{array}$ & $\begin{array}{l}\text { FUNDEPPO } \\
\text { (Mexico) }\end{array}$ \\
\hline Certifying body & $\begin{array}{l}\text { SCS Global } \\
\text { Services }\end{array}$ & FLO-Cert & IMO Swiss AG & Multiple certifiers \\
\hline $\begin{array}{l}\text { Selected major } \\
\text { licensee firms }\end{array}$ & $\begin{array}{l}\text { Green Mountain } \\
\text { Coffee; Starbucks; } \\
\text { Dole; Hershey; } \\
\text { J.M. Smucker }\end{array}$ & $\begin{array}{l}\text { Divine Chocolate; } \\
\text { Ben \& Jerry's; } \\
\text { Starbucks; } \\
\text { Wholesome } \\
\text { Sweeteners }\end{array}$ & $\begin{array}{l}\text { Guayaki Yerba } \\
\text { Mate; Dr. } \\
\text { Bronner's; Theo } \\
\text { Chocolate }\end{array}$ & $\begin{array}{l}\text { Equal Exchange; } \\
\text { Discovery Islands } \\
\text { Organics; Dean's } \\
\text { Beans; } \\
\text { Just Coffee }\end{array}$ \\
\hline $\begin{array}{l}\text { Governance } \\
\text { representation by } \\
\text { organized small } \\
\text { producers? }\end{array}$ & No & $\begin{array}{l}\text { Yes ( } 50 \% \text { of } \\
\text { assembly seats; } 36 \% \\
\text { of board seats) }\end{array}$ & No & Yes $(100 \%)$ \\
\hline $\begin{array}{l}\text { Establishes } \\
\text { minimum or floor } \\
\text { prices? }\end{array}$ & $\begin{array}{l}\text { Yes (FTI } \\
\text { minimums) }\end{array}$ & Yes (FTI minimums) & $\mathrm{No}^{\mathrm{a}}$ & $\mathrm{Yes}^{\mathrm{b}}$ \\
\hline $\begin{array}{l}\text { Requires pre- } \\
\text { harvest financing? }\end{array}$ & $\begin{array}{l}\text { Organized } \\
\text { producers only } \\
\text { (if requested) }^{\mathrm{c}}\end{array}$ & $\begin{array}{l}\text { Yes }(60 \%, \text { if } \\
\text { requested })\end{array}$ & $\begin{array}{l}\text { Yes }(50 \% \text {, if } \\
\text { requested })\end{array}$ & $\begin{array}{l}\text { Yes }(60 \% \text {, if } \\
\text { requested })\end{array}$ \\
\hline $\begin{array}{l}\text { Code or auditing to } \\
\text { screen out firms } \\
\text { with labor/ } \\
\text { environmental } \\
\text { violations? }\end{array}$ & No & No & Yes & Yes \\
\hline $\begin{array}{l}\text { Auditing of firms' } \\
\text { business and labor } \\
\text { practices along } \\
\text { entire product } \\
\text { chain? }\end{array}$ & No & No & Yes & No \\
\hline
\end{tabular}

Sources for Tables 1 and 2: Bio Foundation 2011a, 2011b, 2011c, 2013; Fair World Project 2014a; Fairtrade International 2011, 2011b, 2012, 2013a, 2014a, 2014b; Fair Trade USA 2012, 2013a, 2013b, 2013c, 2014; FUNDEPPO 2013a, 2013b, 2014a, 2014b; IMO n.d.; French Fair Trade Platform et al. 2015.

\footnotetext{
${ }^{a}$ Negotiated sales prices must cover costs of production. Allows but does not require a base price for hired labor operations.

${ }^{\mathrm{b}}$ SPP minimums are above FTI minimums for coffee and other products.

${ }^{\mathrm{c}}$ Fair Trade USA states that it is following FTI standards for organized smallholders for the time being.
} 


\section{Prices, prepayment, and bad actors}

As Table 1 indicates, FTUSA continues to use the FTI minimum price levels and premiums despite its split from the international system, along with Fairtrade America. At least in coffee, these price floors are widely viewed by producers as inadequate to cover their costs and those of their organizations, despite recent increases (Bacon 2010). SPP has developed its own minimum prices and fair trade and organic premiums, all of which are higher than the FTI levels (Fundeppo 2014b). Fair for Life does not specify exact minimum prices, leaving buyers and sellers to negotiate prices, although it does mandate that contracts include a farmgate price, an element missing from the other systems (Bio Foundation 2013). On the issue of preharvest payment to producers, Fairtrade America, Fair for Life, and SPP all stipulate that prepayment is mandatory when requested by buyers, but a key question is whether organizations feel sufficiently empowered in their negotiations with buyers to insist on this provision. ${ }^{9}$ A third issue is whether certification includes an auditing process that screens out firms with records of human rights, labor or environmental violations, even if they meet the certification requirements. While Fair for Life and SPP both incorporate this issue, neither FTUSA nor Fairtrade America do. Additionally, Fair for Life is the only label that mandates compliance with its standards along the product chain, including labor practices in the North.

Policies on labeling, ingredients, and minimum purchase levels

As Table 2 shows, this is one of the areas of greatest difference between the seals. FTI and FTUSA both require that a product contain a minimum of only 20 percent certified ingredients to use a modified version of the fair trade seal that identifies the certified ingredient, such as cocoa or sugar. SPP requires a 50 percent minimum, and Fair for Life has an 80 percent minimum threshold (Bio Foundation 2011b; Fair Trade USA 2013a; Fundeppo 2013a). Another 
TABLE 2: U.S. Fair Trade Certifications: Labeling, Ingredient, Plantation, and Hired Labor Policies

\begin{tabular}{|c|c|c|c|c|}
\hline & $\begin{array}{l}\text { Fair Trade USA } \\
\text { (FTUSA) }\end{array}$ & $\begin{array}{l}\text { Fairtrade America } \\
\text { (FTI) }\end{array}$ & Fair for Life & $\begin{array}{l}\text { Small Producers' } \\
\text { Symbol (SPP) }\end{array}$ \\
\hline $\begin{array}{l}\text { Requires minimum } \\
\text { level of fair trade } \\
\text { purchases for firm to } \\
\text { use seal? }\end{array}$ & No & No & $\begin{array}{l}\text { Yes }(10 \% \text { of total } \\
\text { volume) }\end{array}$ & $\begin{array}{l}\text { Yes }(5 \% \text { of total } \\
\text { volume, rising by } \\
5 \% \text { per year to } \\
25 \%)\end{array}$ \\
\hline $\begin{array}{l}\text { Multi-ingredient } \\
\text { products: minimum } \\
\text { \% fair trade content } \\
\text { to use modified seal } \\
\text { on product package }\end{array}$ & $20 \%$ minimum & $20 \%$ minimum $^{d}$ & $80 \%$ minimum & $50 \%$ minimum \\
\hline $\begin{array}{l}\text { Mandates that all } \\
\text { commercially } \\
\text { available FT } \\
\text { ingredients be used? }\end{array}$ & $\begin{array}{l}\text { No (except for } \\
\text { coffee, tea, cocoa, } \\
\text { quinoa) }\end{array}$ & Yes $^{\mathrm{d}}$ & Yes & Yes \\
\hline $\begin{array}{l}\text { Permits certification } \\
\text { of plantation } \\
\text { products? }\end{array}$ & Yes (all products) & $\begin{array}{l}\text { Yes (except coffee, } \\
\text { cocoa, cotton, rice, } \\
\text { honey) }\end{array}$ & Yes (all products) & No \\
\hline $\begin{array}{l}\text { Hired labor } \\
\text { standards for } \\
\text { farmworkers }\end{array}$ & $\begin{array}{l}\text { General labor } \\
\text { standards based on } \\
\text { ILO conventions, } \\
\text { SA } 8000 \text { standards }\end{array}$ & $\begin{array}{l}\text { Detailed labor } \\
\text { standards } \\
\text { incorporating ILO } \\
\text { conventions; } 2014 \\
\text { revisions strengthen } \\
\text { right to organize, } \\
\text { collective } \\
\text { bargaining }\end{array}$ & $\begin{array}{l}\text { Detailed labor } \\
\text { standards based on } \\
\text { ILO and other } \\
\text { conventions; } \\
\text { strengthened } 2013 . \\
\text { Point system to } \\
\text { achieve } \\
\text { certification }\end{array}$ & $\begin{array}{l}\text { No hired labor } \\
\text { certification. }\end{array}$ \\
\hline $\begin{array}{l}\text { Allocation of FT } \\
\text { premium in } \\
\text { plantation settings }\end{array}$ & $\begin{array}{l}\text { Fair Trade } \\
\text { Committee (labor } \\
\& \text { management } \\
\text { representation) } \\
\text { allocates } \\
\text { premiums }\end{array}$ & $\begin{array}{l}\text { Fairtrade Premium } \\
\text { Committee (worker } \\
\text { majority; nonvoting } \\
\text { management } \\
\text { minority) allocates } \\
\text { premiums }\end{array}$ & $\begin{array}{l}\text { Worker assembly } \\
\text { or Premium fund } \\
\text { committee } \\
\text { allocates } \\
\text { premiums (no } \\
\text { mgmt. rep. req'd.) }\end{array}$ & (Not applicable) \\
\hline $\begin{array}{l}\text { Living wage } \\
\text { standards for } \\
\text { laborers? }\end{array}$ & $\begin{array}{l}\text { No binding } \\
\text { requirement }\end{array}$ & $\begin{array}{l}2014 \text { revisions } \\
\text { mandate progress } \\
\text { toward living wages }\end{array}$ & $\begin{array}{l}\text { No binding } \\
\text { requirement }\end{array}$ & (Not applicable) \\
\hline
\end{tabular}

\footnotetext{
dFTI's "Fairtrade Sourcing Partnership" (for cocoa, sugar, cotton, gold) has no requirements for minimum FT content or using all commercially available FT ingredients. FSP products use a modified version of the FTI seal on packaging, but this is not permitted in the U.S. and Canada.

${ }^{\mathrm{e}}$ Also strengthens protections against discrimination and child/forced labor.
} 
component of this issue is commercial availability, or the long-accepted principle that "all [ingredients] that can be fair trade certified must be." FTUSA adheres to this requirement only for four products, including coffee, while both SPP and Fair for Life adhere fully to the "all that can be" rule, as does Fairtrade America in the United States ${ }^{10}$ (Fair World Project 2014a). Another debate centers on the minimum volume of fair trade purchases needed in order for a firm to be able to use the seal at all. Fair Trade USA and FTI require no minimum levels for entry, which critics argue eliminates the incentive to raise purchases over time. The other two seals do require minimum purchase levels: Fair for Life mandates a 5 percent threshold, and SPP requires that firms reach 25 percent by the sixth year of certification (Bio Foundation 2013; Fundeppo 2013a).

\section{Hired labor, plantations, and premium allocation}

Arguably the most contested policy question in fair trade is whether hired labor and plantation production may be certified — and if so, which crops and under what conditions. As Table 2 illustrates, FTUSA now allows plantation production of any crop. FTUSA is already conducting a pilot program with certified coffee from a Brazilian plantation, which is being sold by Whole Foods Market under its Allegro brand, bearing the same seal as coffee from smallfarmer cooperatives (Fair World Project 2014b). Fair for Life also permits plantation production of any crop, although its full-chain auditing policy functionally excludes most large transnational firms. Fairtrade America, applying the standards of its parent FTI, so far has kept closed to plantations the key crops produced by small farmer groups mentioned above; however, this policy will be reviewed in 2015 (Renard 2015). SPP is the only seal that prohibits all crops produced on plantations. Of the three seals with hired labor standards, Fairtrade America's are the most rigorous and specific. Beyond recently strengthening labor rights protections, FTI has 
also moved to codify living wages standards, making Fairtrade America the only U.S. label to include such stipulations (Fairtrade International 2014a). Fair for Life's hired labor standard was also recently strengthened and is fairly detailed (Bio Foundation 2011b). FTUSA's farmworker standard, on the other hand, is the most general and least rigorous of the four (Fair Trade USA 2014). The three seals permitting plantations also vary on the composition of the body that allocates fair-trade premiums for workers. FTI standards stipulate that labor have a majority (and management representatives are non-voting), while Fair for Life encourages but does not require a management presence on its "premium fund committees." FTUSA simply mandates that the "joint body" be composed of workers and management.

\section{Correspondence with World Fair Trade Organization principles}

Figure 1 depicts the number of excerpts in the four standards that were coded to each of the ten WFTO Principles, offering an illustration of their relative emphases. Some of the principles are emphasized relatively equally across all four labels. "Transparency and accountability," for example, receives the greatest emphasis for three of the four labels (25 percent of the organization's total or higher), and a close second for FTI (23.5 percent). Other principles that receive lower emphasis, but have roughly similar percentages in all four labels, include "ensuring no child and forced labor," "providing capacity building," and "creating opportunities

for economically disadvantaged producers." Fair Trade USA's standards, however, give somewhat greater emphasis to the first two of these principles, and less emphasis to the last, than the other seals.

For other WFTO principles, there is more divergence among the seals. Fair Trade USA's and FTI's standards place more emphasis on criteria that correspond to "commitment to nondiscrimination, gender equity and women's economic empowerment, and freedom of 
Figure 1: Distribution of Standards Document Excerpts Corresponding to World Fair Trade Organization's 10 Principles of Fair Trade

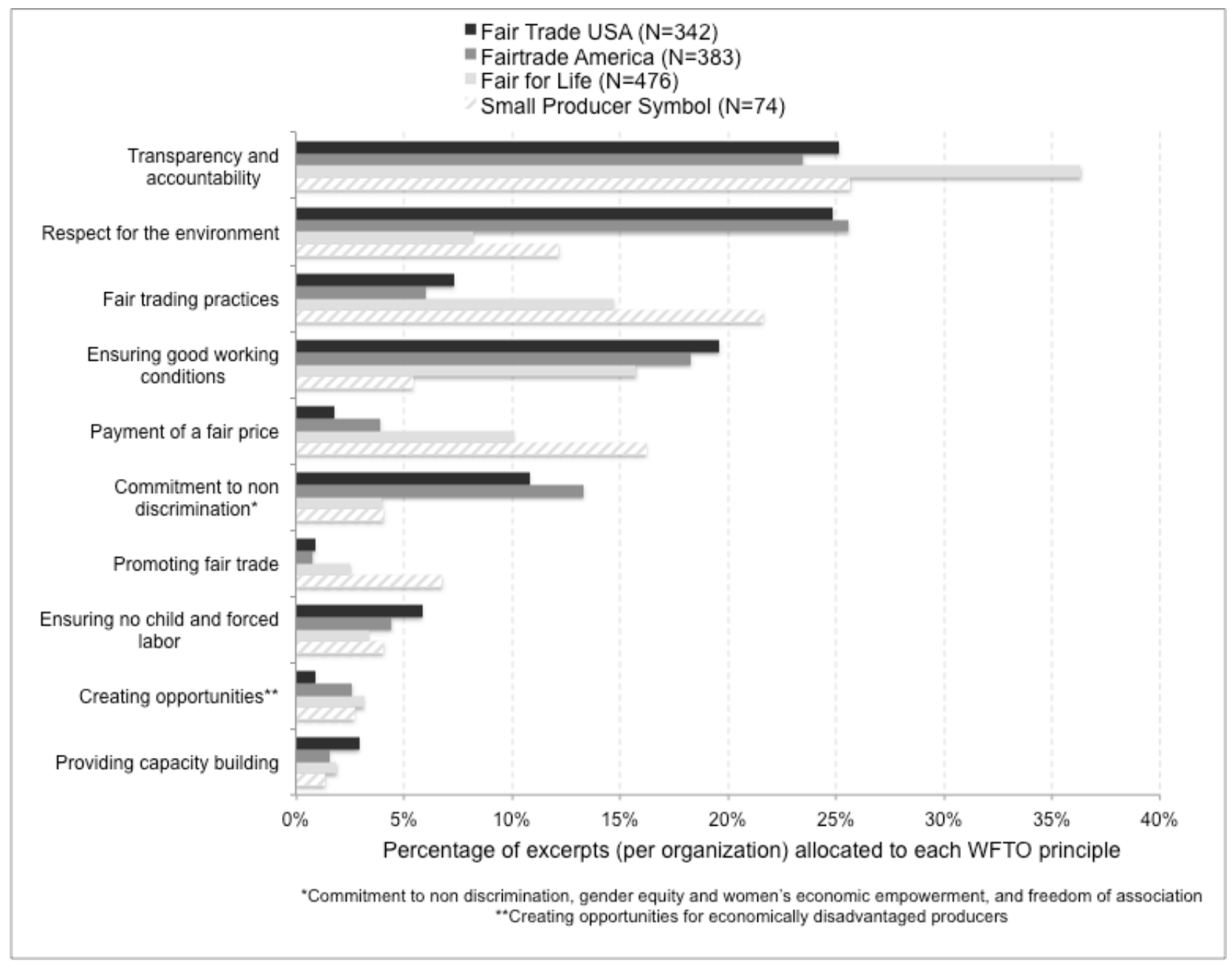

Source documents: Fundeppo 2010, Bio Foundation 2011a, Fairtrade International 2011, Bio Foundation 2011b, Bio Foundation 2011c, Fundeppo 2012, Fundeppo 2013a, Fair Trade USA 2013b, Fair Trade USA 2013c, Fair Trade USA 2014, Fairtrade International 2014a, Fairtrade International 2015. 
association." The latter category is quite broad, but it was most frequently coded for excerpts mentioning freedom of association and protections for labor organizing. FTI's highest ranking in this category may be evidence of the involvement by unions in revising its hired labor standards. Both FTUSA and FTI also place greater stress on "respect for the environment," due to greater detail on pesticide restrictions and worker safety practices. Fair for Life, along with Fair Trade USA and FTI, place far more emphasis on "ensuring good working conditions" than SPP, which as noted above, is the only label that prohibits certification of plantations..

The seals also diverge on the principles of "fair trading practices," "payment of a fair price," and "promoting fair trade." Fair for Life and SPP both place much more emphasis on each of these principles than do Fair Trade USA and FTI. "Payment of a fair price," for example, accounts for $16.2 \%$ of SPP's codes and $10.1 \%$ of Fair for Life's codes, compared to only 3.9\% for FTA and 1.8\% for Fair Trade USA. Although SPP's percentage was slightly higher than Fair for Life for all three of these principles, Fair for Life's standards documents are longer and provide a far greater amount of detail on these issues.

\section{Discussion: Assessing Contending Fair Trade Standards}

This section turns to assessing the competing seals, with a focus on both the social relations and the agrifood practices that are facilitated (or precluded) by each. Who is the fairest of them all? Clearly the answer to this subjective question depends on whose interests the standards serve or hamper. A brief discussion of each seal highlights some of the most salient elements.

Fair Trade USA's label (although recently redesigned) continues to have very high recognition among U.S. consumers. FTUSA has retained many of its original licensees, including the largest multinational firms and a range of medium-sized firms, but virtually none of the movement-oriented companies. It poses no obstacles to the entry of large firms, to 
"dabbling" in fair trade at low purchase volumes, or to firms that engage in problematic practices in other areas. In allowing unlimited certification of crops grown in hired labor situations, FTUSA poses few barriers to conventional agribusiness practices, other than the lowest common denominators among all the seals: compliance with national labor laws, and a prohibition on the most toxic agrochemicals and genetically engineered organisms. The FTUSA seal makes no distinction between crops grown on plantations and those from small producers, nor between organized and unorganized smallholders (Fair Trade USA 2013c). Nevertheless, while the FTUSA seal sets a lower bar in these and other areas, its standards do prohibit some of the worst labor abuses in global agribusiness and ban the worst agrochemicals. Thus it could be viewed either as preferable to no certification at all for the largest TNCs since it does encode mild reforms and applies to high product volumes, or as providing an unacceptably lowered floor that may permit large firms to receive certification for existing supply chains with negligible changes.

Fairtrade America, in applying the international standards of its parent FTI, is the more rigorous of the two seals with very large corporate firms as licensees. It has more stringent rules than either FTUSA or Fair for Life regarding hired labor practices, and those rules have continued to be strengthened. In limiting the certification of coffee and several other key crops to smallholder production, Fairtrade America has so far kept approximately three-quarters of the market (by value) closed to plantations (Fairtrade International 2014a). Thus, its certification poses non-negligible barriers to conventional agribusiness practices. Additionally, FTI is second only to SPP in the governance and ownership role played by small producer organizations, who have exerted substantial influence on some of the certifier's standards and pricing decisions. On the other hand, these standards do only slightly more than FTUSA to protect against fairwashing by large corporations, and do not screen out "bad actor" firms. 
The Fair for Life certification represents a somewhat idiosyncratic mix of rigor and permissiveness. Its full-chain scrutiny of business and labor practices, and its greater emphasis on principles of transparency and accountability, is likely to exclude or deter many large corporate firms. On the other hand, Fair for Life certifies plantations of any crop. Fair for Life has the strongest labeling and ingredient policies of the four, including the highest minimum percentage requirement for certified ingredients, thus likely posing the greatest obstacles to fairwashing by licensees. Its pricing policy is somewhat contradictory, avoiding minimum prices for any products but offering the potential for guaranteed farmgate prices to producers.

Of the four seals, the Small Producer Symbol arguably hews most closely to the fair trade movement's original model and founding principles by certifying only the products of organized small farmers, who are also the owners of the seal. Its code of conduct explicitly incorporates a "good actor" dimension, backed by the threat of decertification. SPP's rising threshold for companies' fair trade purchase volumes is the strongest of any seal, preventing some of the fairwashing and free-rider issues that have occurred with other seals. Although it does not scrutinize firms' Northern operations (as does Fair for Life), by prohibiting plantation production, stipulating the highest minimum prices, and establishing a higher minimum level of certified ingredients, SPP creates the highest barriers of the four seals to conventional agrifood practices. However, as of this writing SPP remains quite small, with 60 producer groups and only nine licensed firms offering a narrow range of products (Fundeppo 2014a; Fundeppo 2014c).

What does this fracturing of the U.S. fair trade certificatison landscape indicate about the current balance of forces within the movement? With the end of FTUSA's monopoly, and particularly since 2012 , the U.S. fair trade field is now open, and firms are able to forum-shop 
for the certification(s) most amenable to their needs. ${ }^{11}$ Thus the "roster" of licensee firms for each seal reveals much about the interest groups each standard serves, and the limits each poses to conventional agrifood actors and practices. The breakdown of licensee firms discussed above suggests that Fair for Life and especially SPP represent more rigorous standards that have drawn many smaller and many medium-sized movement-oriented firms, while Fairtrade America represents a continuation of the status quo ante (with the bulk of production reserved for small producers but also substantial space for agribusiness) that has drawn both medium-sized movement-oriented companies and some large corporate firms. FTUSA's new "Fair Trade for All" standards constitute a lowering of the bar to include previously nonconforming plantation agriculture practices and commodity chains, while at the same time modestly regulating labor and environmental practices in that arena, and this seal has retained the largest corporate agrifood firms. The development of the Fair for Life and SPP seals can be read as a countermovement by two key segments of the fair trade movement—-movement-oriented retailers and organized small producers - that have been opposed to the weakening of standards, which was most pronounced in the U.S. case. Yet at least at the present moment, the rigor of these four certifications is more or less inversely proportional to their scale.

Based on our analysis of these four different approaches to the functional definition of "fair trade," we reach two conclusions. First, we contend that this standards contestation reflects a more fundamental division within the fair trade movement and system, which predates FTUSA's split from the FTI system and is centered on the question of the movement's central purpose. That is, should fair trade serve primarily as a tool to leverage social justice for small peasant producers, or should it be primarily a device to modestly ameliorate labor conditions in agribusiness? According to the Fair World Project, "The central issues that the Fairtrade system 
must now address are what agricultural model to promote and how to balance two different logics within the same certification system" (French Fair Trade Platform et al. 2015). This division emerges from distinct visions of the core function of fair trade, which reflects both divergent values and the structural interests of different groups of market actors in the system, leading to standards that facilitate distinct sets of social relations, pricing and labor practices, and production forms.

Second, the case of U.S. fair trade also departs from prevailing understandings about the dynamics of contestation between competing certifications. As we discuss above, scholars have argued that in most cases of ecolabels and agrifood standards, an initial high-bar initiative grounded in a social movement or civil society is later challenged or supplanted by weaker certifications that are more amenable to conventional industry actors. Examples of this pattern include sustainable forestry (Bartley 2007), sustainable tuna fishing (Miller and Bush 2014) and green building certifications (Smith and Fischlein 2010). However, in the case of fair trade the dynamics diverge from that pattern. Here, the original stringent social movement-based initiative became weakened by industry (most pronounced in the U.S. context), but due to the structure of the international system, Transfair USA retained a monopoly over U.S. certification even while the standards were being weakened, precluding true competitors. When such competitors did eventually emerge, they all represented more-rather than less—rigorous standards in many areas, pulling the bar upward. Thus, the case of fair trade certification in the U.S. necessitates a reevaluation or broadening of the frameworks used to analyze inter-standards contestation to account for these dynamics. 


\section{Conclusions}

How might producers, consumers, and activists navigate amid this confusing welter of competing fair-trade labels and claims? The proliferation of fair trade seals clearly alters the fair trade consumption landscape and places a greater burden on consumers who seek options that enhance rather than weaken social justice in the global food system, albeit within the constrained realm of the marketplace. While fair-trade activists once could advise shoppers simply to "look for the label," informed purchasing now obliges consumers to engage in additional research and balance multiple factors. Yet the fragmentation at least raises the hopeful prospect that such competition will have a salutary effect, educating consumers to switch to the more rigorous seals and potentially pushing the weakest to raise their lowered bar, or at least to halt further dilution. Another possibility is that the fragmentation will cement into place the fundamental splits already existing in the fair trade system, with weaker standards creating a lower floor for labor practices in agribusiness on one hand, and multiple variants of a higher floor for small and medium firms still dedicated to the original smallholder model on the other. Such spaces of resistance may be challenging to maintain, given the much greater resources available to the agribusiness-supported labels. In any case, both consumers and producers will certainly have opportunities to influence how each of these models fares in coming years.

This article has made two principal arguments. First, the fracturing of fair trade certification in the United States illustrates broader institutional and ideological divisions within

the fair trade system and movement, centered around the question of which production forms and actors should be privileged: organized peasant smallholders, or plantation agriculture employing hired laborers. Advocates of the latter vision argue that limiting fair trade certification to small farmers denies the leverage of the seal to exploited plantation workers, and that fair trade is the 
best route to reform labor practices in corporate agriculture (Neuman 2011; Rice 2012). On the other hand, defenders of the small producer model claim that expanding fair-trade certification of plantations undercuts small producers and permits fairwashing by agrifood TNCs with problematic records in labor rights, environmental practices, and other areas. They accept that labor conditions in global agribusiness desperately need regulation and reform, but argue that the fair trade model — created for and by marginalized small peasant producers — is not the appropriate device to achieve such a goal (Dickinson 2011; Zinn 2012). These divisions predate FTUSA's dramatic break from the international fair trade standards, but that institutional split has made the existing divisions more apparent, and has opened the institutional field of fair trade in the U.S. to dueling standards regimes that encode sharply different visions of social justice in the agrifood system. The widening divergence between these opposing models of fair trade is the most likely future trajectory for fair trade in the United States, and also increasingly at the global level.

Second, we have argued that this case requires a reevaluation of the dominant frameworks used by scholars to analyze contexts in which multiple private standards compete within a single arena. While it confirms Smith and Fischlein's (2010) argument that competition among rival standards in the same arena results from the exclusion of important stakeholders (in this context organized small producers and movement-oriented firms), the case of fair trade in the U.S. departs from the pattern observed in other contested standards arenas, in which an initial rigorous system located in civil society is supplanted by competing, lower-bar systems from either industry or other NGO actors. In this case, the longstanding monopoly on fair trade licensing by the national bodies in the FLO/FTI structure prevented the emergence of competing systems until recently. Rather than lowering the bar further, the newer competing systems in fair trade in 
the U.S. instead all pose more rigorous barriers to conventional labor, production, trading, labeling and pricing practices.

Thus, the fracturing of the U.S. fair trade certification system need not be viewed as a negative development. On the contrary, it offers new opportunities to redefine and reenvision the contours of fair trade in the U.S., as well as a path for consumers to express their support for alternative arrangements - to "fight standards with standards" (Mutersbaugh 2005a). In this respect, U.S. fair-trade consumers presently have a wider range of options than do their counterparts elsewhere in the global North. The current context also provides genuinely alternative pathways for small producer organizations and movement-oriented retailers.

It is ironic but perhaps fitting that the United States, whose key fair trade body arguably contributed the most to setting the stage for corporate entry with few safeguards at the international level, and thus to the weakening of fair trade standards more generally, is at this point the nation with the broadest variety of competing models of certified fair trade, ranging from the reformist to the potentially transformative. It thus offers an intriguing laboratory in which to examine not only the dynamics of intramovement standards contention, but also the potentialities and limitations of market tools for advancing social justice in a neoliberal era. 


\section{REFERENCES}

Bacon, C. 2010. Who decides what is fair in fair trade? The agri-environmental governance of standards, access, and price. Journal of Peasant Studies 37(1): 111-147.

Bartley, T. 2007. How foundations shape social movements: The construction of an organizational field and the rise of forest certification. Social Problems 54(3): 229-255.

Bennett, E. A. 2015. Fairtrade International governance. In Handbook of Research on Fair Trade, eds. L. T. Raynolds and E. A. Bennett, 80-101. Northampton, MA, Edward Elgar.

Besky, S. 2008. Can a plantation be fair? Paradoxes and possibilities in fair trade Darjeeling tea certification. Anthropology of Work Review 29(1): 1-9.

Besky, S. 2010. Colonial pasts and fair trade futures: Changing modes of production and regulation on Darleejing tea plantations. In Fair trade and social justice: Global ethnographies, eds. S. Lyon and M. Moberg, 97-112. New York: NYU Press.

Besky, S. 2014. The Darjeeling distinction: Labor and justice on fair-trade tea plantations in India. Berkeley: University of California Press.

Bio Foundation. 2011a. Fair for Life social \& fairtrade certification programme, version 2011: Control module 1: Labeling and control criteria. Wienfeld, Switzerland: IMO.

Bio Foundation. 2011b. Fair for Life social \& fairtrade certification programme, version 2011: Control module 2: Criteria for hired labour operations. Wienfeld, Switzerland: IMO.

Bio Foundation. 2011c. Fair for Life social and fairtrade certification programme, version 2011: Control module 3: Criteria for producer groups. Wienfelden, Switzerland: IMO.

Bio Foundation. 2013. Fair for Life social and fairtrade certification programme, version December 2013. Wienfelden, Switzerland: IMO.

Busch, L. 2011. Standards: Recipes for reality. Cambridge, MA: MIT Press.

Dickinson, R. 2011. An analysis of fair trade: reflections from a co-founder. Presentation at InterReligious Task Force on Central America conference, Cleveland, OH, October 22.

Doherty, B., I. A. Davies and S. Tranchell. (2013). Where now for fair trade? Business History 55(2): 161-189.

Equal Exchange. 2010. Why is Equal Exchange now using Institute for Marketecology (IMO) for most of our products? http://www.equalexchange.coop/why-is-equal-exchange-nowusing-institute-for-marketecology-imo-for-most-of-our-products-. Accessed 15 October 2010.

Fair Trade USA. 2012. Certification manual: Fair Trade USA. Oakland, CA, FTUSA.

Fair Trade USA. 2013a. Fair Trade USA multiple ingredients product policy. Oakland, CA: FTUSA.

Fair Trade USA. 2013b. Fair Trade USA trade standard, version 1.0. Oakland, CA: FTUSA.

Fair Trade USA. 2013c. Fair Trade USA independent smallholders standard, version 1.1. Oakland, CA: FTUSA.

Fair Trade USA. 2014. Fair Trade USA farm workers standard, version 1.1. Oakland, CA: FTUSA.

Fair Trade USA. 2015. Fair Trade USA: Products and partners. http://fairtradeusa.org/productspartners. Accessed 15 September 2015.

Fair World Project. 2014a. Eco-social and fair trade certifier analysis. http://fairworldproject.org/overview/certifier-analysis/. Accessed 9 February 2014. 
Fair World Project. 2014b. Tell Allegro Coffee: Play fair. http://salsa3.salsalabs.com/o/2002/p/dia/action/public/?action_key=8352. Accessed $24 \mathrm{July}$ 2014.

Fairtrade America. 2013. Fairtrade America: About the Fairtrade mark. http://fairtradeamerica.org/fairtrade/about-fairtrade. Accessed 23 July 2014.

Fairtrade International. 2011. Fairtrade standard for small producer organizations (version 1.2). Bonn, Germany: Fairtrade International.

Fairtrade International. 2012. Monitoring the scope and benefits of fairtrade: Fourth edition. Bonn, Germany: Fairtrade International.

Fairtrade International. 2013a. Monitoring the scope and benefits of fairtrade: Fifth edition. Bonn, Germany: Fairtrade International.

Fairtrade International. 2013b. Q\&A on Fairtrade International and Fair Trade USA. http://www.fairtrade.net/897.html. Accessed 24 April 2014.

Fairtrade International. 2014a. Fairtrade standard for hired labour (version 1.0). Bonn, Germany: Fairtrade International.

Fairtrade International. 2014b. Fairtrade sourcing partnerships for cocoa and sugar: An introduction. Bonn, Germany: Fairtrade International.

Fairtrade International. 2015. Fairtrade Trader Standard (version 1.0). Bonn, Germany: Fairtrade International.

French Fair Trade Platform, Fair World Project and FairNess. 2015. International guide to fair trade labels (edition 2015). Bondues, France: Plate-Forme Pour le Commerce Equitable.

Fridell, M., I. Hudson and M. Hudson. 2008. With friends like these: The corporate response to fair trade. Review of Radical Political Economy 40(1): 8-34.

Fundeppo. 2010. Code of conduct: Small Producers' Symbol (version 1, ed. 2). Mexico City: Fundeppo.

Fundeppo. 2012. Informative guide for small producer organizations. Mexico City: Fundeppo.

Fundeppo. 2013a. General standard of the Small Producers Symbol (version 7). Mexico City: Fundeppo.

Fundeppo. 2013b. Specific parameters: Standards for Small Producers' Symbol (version 2, edit 2). Mexico City: Fundeppo.

Fundeppo. 2014a. List of certified small producers' organizations. Mexico City: Fundeppo.

Fundeppo. 2014b. List of sustainable prices: General standard of Small Producers' Symbol (version 4, edit 2). Mexico City: Fundeppo.

Fundeppo. 2014c. List of registered buyers. Mexico City: Fundeppo.

Gogoi, P. 2008. Is fair trade becoming 'fair trade lite'? Business Week, June 18.

Hatanaka, M., J. Konefal and D. H. Constance. 2012. A tripartite standards regime analysis of the contested development of a sustainable agriculture standard. Agriculture and Human Values 29(1): 65-78.

Howard, P. H. and P. Allen. 2010. Beyond organic and fair trade? An analysis of ecolabel preferences in the United States. Rural Sociology 75(2): 244-269.

Howard, P. H. and D. Jaffee (2013). Tensions between firm size and sustainability goals: Fair trade coffee in the United States. Sustainability (5): 72-89.

IMO Fair for Life. (n.d.). Fair for Life: become certified. http://www.fairforlife.org/pmws/indexDOM.php?client_id=fairforlife\&page id=become\&la ng iso639=en. Acessed 25 April 2014. 
International Labor Rights Forum. 2013. Theo Chocolate case study: Aiding and abetting: How unaccountable fair trade certifiers are destroying workers' rights. Washington, DC: International Labor Rights Forum.

Jaffee, D. 2007. Brewing justice: Fair trade coffee, sustainability, and survival. Berkeley: University of California Press.

Jaffee, D. 2010. Fair trade standards, corporate participation, and social movement responses in the United States. Journal of Business Ethics 92: 267-285.

Jaffee, D. 2012. Weak coffee: Certification and co-optation in the fair trade movement. Social Problems 59(1): 94-116.

Jaffee, D. and P. H. Howard. 2010. Corporate cooptation of organic and fair trade standards. Agriculture and Human Values 27(4): 387-399.

Lake Research Partners. 2013. Fair trade labeling research: Findings from a nationwide survey of 1003 Americans aged 18 and over. Washington, DC: Lake Research Partners.

Lyon, S. and M. Moberg, eds. 2010. Fair trade and social justice: Global ethnographies. New York: NYU Press.

Makita, R. 2012. Fair trade certification: The case of tea plantation workers in India. Development Policy Review 30(1): 87-107.

Miller, A.M.M and S.R. Bush. 2014. Authority without credibility? Competition and conflict between ecolabels in tuna fisheries. Journal of Cleaner Production, http://dx.doi.org/10.1016/j.jclepro.2014.02.047.

Mutersbaugh, T. 2005a. Fighting standards with standards: Harmonization, rents, and social accountability in certified agrofood networks. Environment and Planning A 37(11): 20332051.

Mutersbaugh, T. 2005b. Just-in-space: Certified rural products, labor of quality, and regulatory spaces. Journal of Rural Studies 21(4): 389-402.

Neuman, W. 2011. A Question of Fairness. The New York Times, November 23.

Preza, M. 2012. President, Coordinadora Latinoamericana y del Caribe de Pequeños Productores del Comercio Justo (CLAC). Personal Communication, May 1, Minneapolis, MN.

Pruijn, G. 2014. Executive Director, SPP and Fundeppo. Personal Communication, February 27, Mexico City.

Raynolds, L. T. 2009. Mainstreaming fair trade coffee: From partnership to traceability. World Development 37(6): 1083-1093.

Raynolds, L. T. 2012. Fair trade: Social regulation in global food markets. Journal of Rural Studies 28: 276-287.

Raynolds, L. T. 2014. Fairtrade, certification, and labor: Global and local tensions in improving conditions for agricultural workers. Agriculture and Human Values 31(3): 499-511.

Raynolds, L. T., D. Murray and A. Heller. 2007. Regulating sustainability in the coffee sector: A comparative analysis of third-party environmental and social certification initiatives. Agriculture and Human Values 24: 147-163.

Raynolds, L. T., D. Murray and J. Wilkinson, eds. 2007. Fair trade: The challenges of transforming globalization. New York: Routledge.

Reed, D. 2009. What do corporations have to do with fair trade? Positive and normative analysis from a value chain perspective. Journal of Business Ethics 86: 3-26.

Renard, M. C. 2003. Fair trade: Quality, market and conventions. Journal of Rural Studies 19(1): 87-96. 
Renard, M. C. 2005. Quality certification, regulation and power in fair trade. Journal of Rural Studies 21(4): 419-431.

Renard, M. C. 2010. In the name of conservation: CAFE Practices and fair trade in Mexico. Journal of Business Ethics 92: 287-299.

Renard, M. C. 2015. Fair trade for small farmer cooperatives in Latin America. In Handbook of research on fair trade, eds. L. T. Raynolds and E. A. Bennett, 475-490. Northampton, MA: Edward Elgar.

Renard, M. C. and A. Loconto. 2013. Competing logics in the further standardization of fair trade: ISEAL and the Símbolo de Pequeños Productores. International Journal of Sociology of Agriculture and Food 20(1): 51-68.

Rice, P. 2012. Fair Trade USA: Why we parted ways with Fair Trade International. http://www.triplepundit.com/2012/01/fair-trade-all-fair-trade-usa-plans-double-impact2015\%. Accessed 11 January 2014.

Schaltegger, S. and M. Wagner. 2011. Sustainable entrepreneurship and sustainability innovation: Categories and interactions. Business Strategy and the Environment 20(4): 222237.

Sherman, S. 2012. The brawl over fair trade coffee. The Nation 295: 22-26.

Smith, A. 2013. What does it mean to do fair trade? Ontology, praxis, and the 'Fair for Life' certification system. Social Enterprise Journal 9(1): 53-72.

Smith, T. M. and M. Fischlein. 2010. Rival private governance networks: Competing to define the rules of sustainability performance. Global Environmental Change 20: 511-522.

Stevis, D. 2015. Global labor politics and fair trade. Handbook of research on fair trade. L. T. Raynolds and E. A. Bennett, eds., 102-119. Northampton, MA: Edward Elgar.

World Fair Trade Organization. 2013. 10 principles of fair trade. http://wfto.com/fair-trade/10principles-fair-trade. Accessed 20 April 2015.

Zinn, R. 2012. FWP's statement on Fair Trade USA's resignation from Fairtrade International (FLO). For A Better World 4: 10-11. 
Daniel Jaffee, Ph.D. is Associate Professor of Sociology at Portland State University. His research examines the politics of fair trade, agrifood certification, social movements around food and agriculture, and contestation over water commodification in the global South and North. He is the author of Brewing Justice: Fair Trade Coffee, Sustainability, and Survival, published by University of California Press, with an updated 2014 edition.

Philip H. Howard, Ph.D. is Associate Professor of Community Sustainability at Michigan State University. His research and teaching focus on food system changes, particularly consolidation in food and beverage industries. He is the author of Concentration and Power in the Food System: Who Controls What We Eat?, published by Bloomsbury Academic in 2016. He also served as president of the Agriculture, Food and Human Values Society from 2015 to 2016, and is currently a member of the International Panel of Experts on Sustainable Food Systems.

\section{NOTES}

1 This governance change was made in 2011 but only fully implemented in 2014 (Bennett 2015).

2 The 2011 FTI increase brought the base price to $\$ 1.40$ per pound, plus a 20 cent fair trade premium, with a 30 cent organic premium - totaling $\$ 1.90$ per pound for organic fair trade coffee.

${ }^{3}$ Authors' calculations, using the U.S. Consumer Price Index (CPI).

${ }^{4}$ According to Renard (2015), this policy will be reviewed in 2015, with the potential for opening these crops to plantation production.

${ }^{5}$ FTI is now revising its hired labor standards to move toward incorporating binding "living wage" language in future versions of the standards.

${ }^{6}$ Small producers are defined as those possessing a maximum of 15 hectares of land and not structurally dependent on hired labor (Fundeppo 2013b).

${ }^{7}$ The analysis and tables cannot depict all dimensions of these standards, and leave out several issues on which differences between the seals are minimal.

${ }^{8}$ These include IMO Control, Certimex, Mayacert, and Biolatina.

9 FTUSA says it is adopting FTI's standards for organized smallholders "as-is" for the present, leaving its adherence to the prefinancing mandate subject to interpretation.

${ }^{10}$ Its parent, FTI, no longer applies this principle outside the U.S. and Canada.

${ }^{11}$ A few brands (including Starbucks) are choosing to maintain more than one of these certifications, while others have forgone certification entirely. 